\title{
ПОКАЗНИКИ ЕНЕРГЕТИЧНОГО ОБМІНУ В СЕРЦЕВІЙ ТКАНИНІ ЕКСПЕРИМЕНТАЛЬНИХ ТВАРИН ЗА УМОВ ВПЛИВУ КАДМІЙ ХЛОРИДУ
}

Вступ. Катіони кадмію можуть надходити в організм людини і тварин з їжею, питною водою й атмосфрерним повітрям. їх дія полягає у пригніченні фрункціонального стану мітохондрій, що призводить до виснаження енергетичних ресурсів та порушення ряду життєво важливих процесів. Кадмій, проникаючи в клітини, взаємодіє з меркаптогрупами, пригнічує ензимні системи енергозабезпечення шляхом заміщення двовалентних металів, які входять до складу ензимів.

Мета дослідження - з'ясувати стан енергетичного обміну в серцевому м'язі експериментальних тварин (щурів) за умов впливу кадмій хлориду.

Методи дослідження. Інтоксикацію здійснювали шляхом внутрішньом'язового введення кадмій хлориду в дозі 1/10 LD50 протягом 10-ти днів. Тварин було поділено на 2 групи: 1-ша - інтактні; 2-га експериментальні, яким вводили кадмій хлорид. Забір матеріалу проводили після декапітації під тіопенталовим наркозом на 1-шу, 14-ту, 28-му доби після завершення введення токсиканту. Показники енергетичного обміну визначали таким чином: активність АТФ-ази, лактатдегідрогенази - ензиматичним методом; концентрацію глюкози - глюкооксидазним методом; рівень піровиноградної, молочної, аденозинтриороссрорної (АТФ) кислот - спектрооротометрично; вміст макро- та мікроелементів (Cd, $\mathrm{Zn}, \mathrm{Cu}$, Mg) - за допомогою атомно-абсорбційного спектрофотометра.

Результати й обговорення. Отримані результати свідчать про посилене використання глюкози серцевим м'язом анаеробним шляхом, оскільки спостерігали підвищення концентрації молочної кислоти. Це підтвердило літературні дані про розвиток гіпоксії за умов дії іонів кадмію. Водночас відмічено зниження рівня аденозинтрифросфрорної кислоти, а також активності АТФ-ази у тканині серця. Встановлено збільшення вмісту магнію (активатора АТФ-ази) та цинку (активатора лактатдегідрогенази) в серці експериментальних тварин.

Висновок. Результати проведених досліджень вказують на порушення енергетичного забезпечення тканин серцевого м'яза за умов кадмієвої інтоксикації, що підтверджується активацією анаеробного окиснення глюкози, зниженням її рівня та вмісту аденозинтрифосфорної кислоти в міокарді.

КЛЮЧОВІ СЛОВА: енергетичний обмін; кадмій хлорид, $\mathrm{Na}^{+}, \mathrm{K}^{+}$-активуюча, $\mathrm{Mg}^{2+}$-залежна АТФ-аза; аденозинтрифоссорна кислота; глюкоза; лактатдегідрогеназа.

ВСТУП. Антропогенний та урбанізаційний вплив посилює дію ксенобіотиків на живі організми. Сполуки кадмію належать до особливо небезпечних речовин, і комісія ФАО/ВООЗ включила їх до переліку тих, що підлягають обов'язковому контролю [1]. Катіони кадмію можуть надходити в організм людини і тварин з їжею, питною водою й атмосорерним повітрям. Вони здатні викликати негативні біологічні ефекти (порушення травлення, всмоктування і засвоєння клітиною поживних речовин) навіть у малих концентраціях [2, 3]. 3 наукової літератури [4, 5] відомо, що визначальним у шкідливій дії іонів кадмію $є$ пригнічення фрункціонального стану мітохондрій, що призводить до виснаження енергетичних ресурсів. Один 3 механізмів дії с Л. Д. Курас, Г. М. Ерстенюк, 2019. іонів кадмію полягає у взаємодії з меркаптогрупами шляхом заміщення двовалентних металів, які входять до складу ензимів [4].

Враховуючи вищесказане, метою цього дослідження було з'ясувати стан енергетичного обміну в серцевому м'язі експериментальних тварин (щурів) за умов впливу кадмій хлориду.

МЕТОДИ ДОСЛІЖЕННЯ. Дослідження проводили на білих безпородних лабораторних щурах-самцях масою 180-220 г, яких утримували на стандартному харчовому раціоні віварію. Токсичне ураження викликали кадмій хлоридом $\left(\mathrm{CdCl}_{2}\right)$. Кадмій хлорид вводили внутрішньом'язово в дозі 1,2 мг/кг маси тіла тварини (1/10 LD $\left.{ }_{50}\right)$ один раз на день протягом 10-ти діб [6]. Інтактним щурам водночас вводили відповідну кількість 
0,9 \% розчину натрій хлориду. Досліджуваних тварин було поділено на 2 групи: 1-ша - інтактні (контроль); 2-га - щури, інтоксиковані кадмій хлоридом. Для дослідження використовували сироватку крові й гомогенат серця. Забір матеріалу проводили згідно з правилами Європейської конвенції про захист хребетних тварин, що використовуються для дослідних та інших наукових цілей (Страсбург, 1986) після декапітації під тіопенталовим наркозом на 1-шу, 14-ту, 28-му доби після завершення введення кадмій хлориду. Показники енергетичного обміну визначали таким чином: активність $\mathrm{Na}^{+}, \mathrm{K}^{+}$-активуючої, $\mathrm{Mg}^{2+}$-залежної АТФ-ази - за різницею активностей за присутності та відсутності уабаїну (строфрантину) [7]; активність лактатдегідрогенази (ЛДГ) - спектрофотометрично із застосуванням набору “Філісіт-Діагностика" (Україна); концентрацію глюкози - глюкооксидазним методом за допомогою набору “Філісіт-Діагностика" (Україна); вміст піровиноградної кислоти - за кількістю похідних 2,4-динітросренілгідразону [8]; рівень молочної кислоти - за реакцією з параоксидифренілом [9]; рівень аденозинтрифросфорної кислоти (АТФ) - за кількістю фоосфору (за модифрікованою методикою Алейникова і Рубцова) [10]. Вміст кадмію, магнію, міді, цинку визначали за допомогою атомно-абсорбційного спектрофотометра С-115 ПК [5, 6]. Отримані результати піддавали статистичному аналізу за загальноприйнятою методикою з використанням критерію t-тесту Стьюдента (Statistica 8) [11].

РЕЗУЛЬТАТИ Й ОБГОВОРЕННЯ. НаЙДОступнішим джерелом енергії для тканин організму є глюкоза. Як показали наші дослідження, в гомогенатах серця спостерігали достовірне $(p \leq 0,001)$ зниження рівня глюкози: в 50 разів на 1-шу добу, в 11 разів - на 14-ту добу та у 22 рази - на 28-му добу після завершення введення кадмій хлориду порівняно з інтактними тваринами (табл. 1). За результатами досліджень метаболітів обміну глюкози, встановлено накопичення в серцевому м'язі лактату і зменшення рівня пірувату. Слід відмітити достовірне $(p \leq 0,001)$ зростання вмісту молочної кислоти, найбільш істотні зміни спостерігали в пізній період експерименту - у 23 рази порівняно 3 контрольною групою. Водночас рівень піровиноградної кислоти знижувався незначною мірою на 1-шу добу спостереження, а на 14-ту і 28-му зменшився на 32 та 40 \% порівняно з інтактними тваринами.

Визначення активності ЛДГ у гомогенатах серцевого м'яза засвідчило достовірне $(p \leq 0,001)$ ії зниження впродовж експерименту. Найбільш істотні зміни спостерігали на 1-шу і 28-му доби в 6,5 та 6 разів порівняно $з$ інтактними.

Отримані результати показали, що за умов кадмієвої інтоксикації енергозабезпечення серцевого м'яза відбувається з активним використанням глюкози. Накопичення лактату вказує на посилення анаеробного окиснення глюкози, що свідчить про розвиток гіпоксії за умов дії іонів кадмію [2, 3].

На підтвердження проведеної кадмієвої інтоксикації ми визначали рівень кадмію в серцевому м'язі. Зокрема, спостерігали достовірне $(p \leq 0,001)$ збільшення вмісту кадмію в серцевій тканині в 41 раз протягом усього періоду дослідження порівняно з інтактними тваринами (рис. 1). Результати досліджень рівня цинку та міді показали, що концентрація цинку достовірно $(p \leq 0,001)$ зростала у 2 рази на 1 -шу і $28-м y$ доби порівняно з інтактними тваринами; водночас відмічено збільшення на 30 \% вмісту міді на 1-шу добу порівняно з контролем.

Концентрація АТФ достовірно $(p \leq 0,001)$ знижувалася у 2 рази протягом усього періоду дослідження порівняно 3 інтактними тваринами (рис. 2). Результати досліджень активності основного ензиму синтезу АТФ - $\mathrm{Na}^{+}, \mathrm{K}^{+}$-активуючої, $\mathrm{Mg}^{2+}$-залежної АТФ-ази (рис. 2) показали достовірне $(p \leq 0,001)$ їі зменшення в 4 рази на 14-ту добу та у 12 разів на 28-му добу порівняно з інтактними тваринами. Концентрація основного активатора АТФ-ази - макроелемента магнію в гомогенатах серця зростала у 2-3 рази протягом усього періоду дослідження порівняно 3 контролем (рис. 2).

Таблиця 1 - Показники енергетичного обміну в серцевій тканині експериментальних тварин за умов впливу кадмій хлориду

\begin{tabular}{|c|c|c|c|c|}
\hline \multirow{2}{*}{ група } & \multicolumn{4}{|c|}{ Показник } \\
\cline { 2 - 5 } & $\begin{array}{c}\text { глюкоза, } \\
\text { ммоль/г тканини }\end{array}$ & $\begin{array}{c}\text { молочна } \\
\text { кислота, } \\
\text { ммоль/г тканини }\end{array}$ & $\begin{array}{c}\text { піровиноградна } \\
\text { кислота, } \\
\text { мкмоль/г тканини }\end{array}$ & $\begin{array}{c}\text { лактатдегідрогеназа, } \\
\text { мкмоль/с·г тканини }\end{array}$ \\
\hline Контроль & $13,23 \pm 4,05$ & $1,67 \pm 0,48$ & $0,167 \pm 0,009$ & $3,33 \pm 0,58$ \\
\hline 1-ша доба & $0,27 \pm 0,08^{*}$ & $4,83 \pm 1,98^{\star}$ & $0,152 \pm 0,039$ & $0,51 \pm 0,16^{\star}$ \\
\hline 14-та доба & $1,16 \pm 0,31^{*}$ & $24,43 \pm 10,36^{*}$ & $0,113 \pm 0,027$ & $0,91 \pm 0,33^{\star}$ \\
\hline 28-ма доба & $0,58 \pm 0,32^{*}$ & $39,53 \pm 8,25^{*}$ & $0,102 \pm 0,019$ & $0,54 \pm 0,15^{\star}$ \\
\hline \hline
\end{tabular}

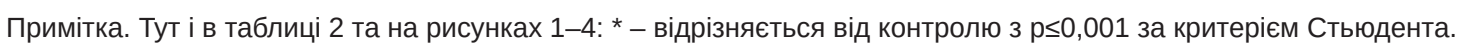



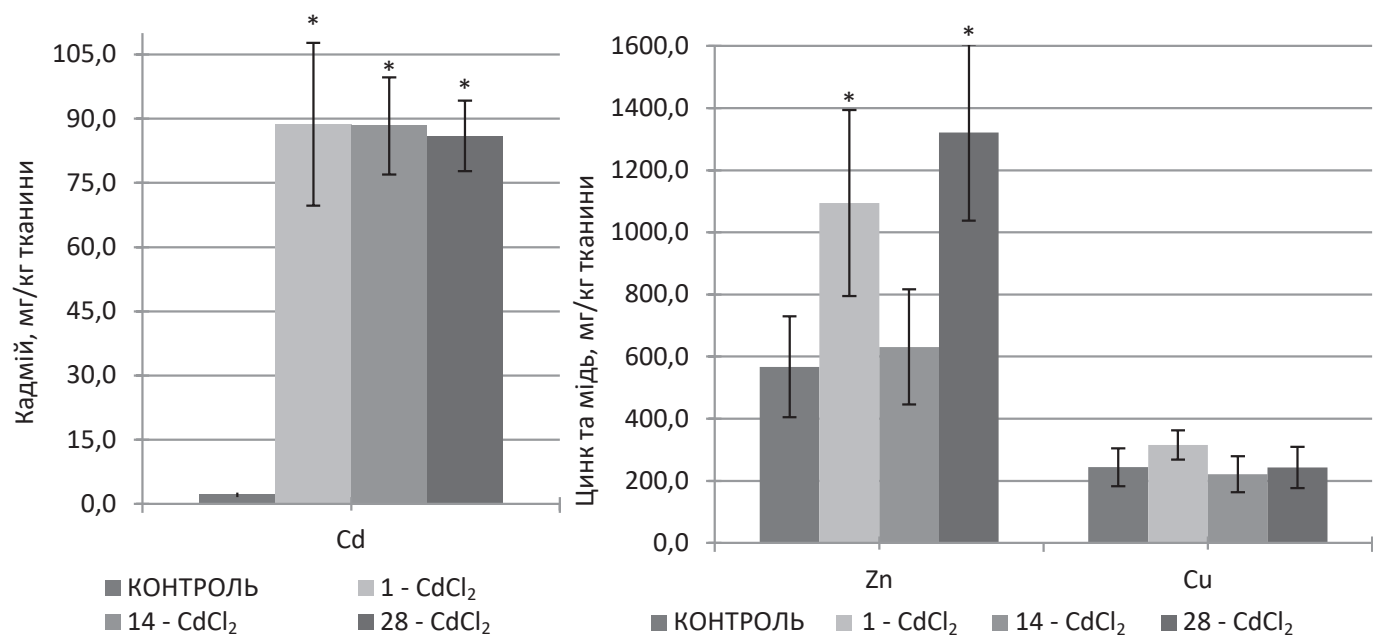

Рис. 1. Вміст кадмію, цинку та міді в серцевій тканині експериментальних тварин за умов впливу кадмій хлориду.
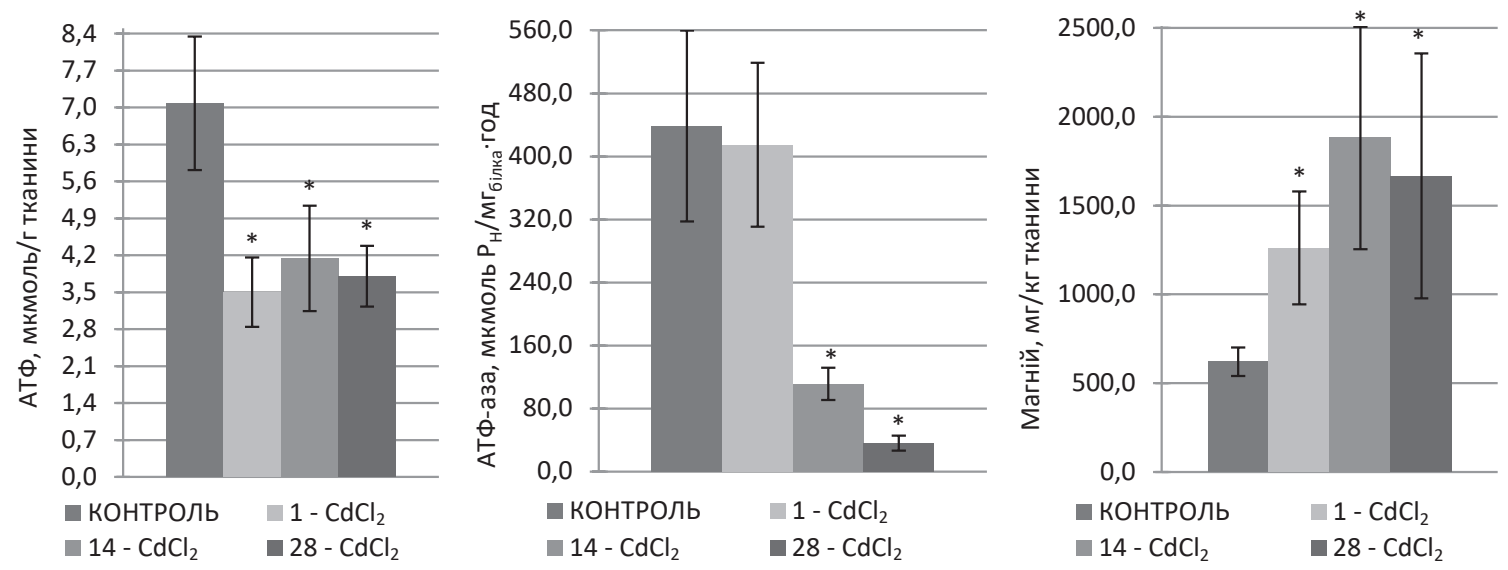

Рис. 2. Вплив кадмій хлориду на концентрацію аденозинтрифоссрорної кислоти і магнію та активність АТФ-ази в гомогенаті серця експериментальних тварин.

Результати досліджень показників енергетичного обміну в сироватці крові показали: зростання рівня глюкози на 55 і 60 \% на 14-ту та 28-му доби (табл. 2); незначне підвищення рівня молочної кислоти на 1-шу добу (табл. 2); зниження концентрації піровиноградної кислоти (табл. 2) на $40 \%$ на 14-ту добу порівняно 3 iнтактними тваринами. Водночас активність ЛДГ достовірно $(p \leq 0,001)$ збільшувалась у 30-60 paзів упродовж усього періоду дослідження (табл. 2).

Рівень кадмію в крові достовірно $(p \leq 0,001)$ зростав у 8-40 разів упродовж усього періоду дослідження порівняно з контролем (рис. 3).

Концентрація цинку достовірно $(\mathrm{p} \leq 0,001)$ підвищувалась у 2 рази на 1-шу та 28-му доби, а міді - на 55 \% на 28-му добу порівняно з інтактними тваринами (рис. 3).

Встановлено достовірне $(p \leq 0,001)$ зниження концентрації АТФ у крові (рис. 4): у 4 рази - на 1-шу добу, в 2,5 раза - на 14-ту добу, у 2 рази - на 28-му добу відносно інтактних тварин. При цьому активність АТФ-ази зростала у 2,5 раза на 1-шу добу $(p \leq 0,001)$, так само концентрація основного активатора АТФ-ази - макроелемента магнію підвищувалась у 2,0-2,5 раза в ранній і пізній періоди дослідження порівняно з контролем (рис. 4).

Таблиця 2 - Показники енергетичного обміну в сироватці крові експериментальних тварин за умов впливу кадмій хлориду

\begin{tabular}{|c|c|c|c|c|}
\hline \multirow{2}{*}{ Група } & \multicolumn{4}{|c|}{ Показник } \\
\cline { 2 - 5 } & $\begin{array}{c}\text { глюкоза, } \\
\text { ммоль/л }\end{array}$ & $\begin{array}{c}\text { молочна кислота, } \\
\text { ммоль/л }\end{array}$ & $\begin{array}{c}\text { піровиноградна кислота, } \\
\text { мкмоль/л }\end{array}$ & $\begin{array}{c}\text { лактатдегідрогеназа, } \\
\text { мкмоль/с·л }\end{array}$ \\
\hline Контроль & $5,58 \pm 0,63$ & $0,238 \pm 0,070$ & $0,0192 \pm 0,0005$ & $0,066 \pm 0,026$ \\
\hline 1-ша доба & $6,69 \pm 1,24$ & $0,266 \pm 0,040$ & $0,0285 \pm 0,0022$ & $1,852 \pm 0,571^{*}$ \\
\hline 14-та доба & $8,94 \pm 2,36$ & $0,133 \pm 0,071$ & $0,0118 \pm 0,0004$ & $3,991 \pm 1,368^{*}$ \\
\hline 28-ма доба & $8,65 \pm 1,19^{*}$ & $0,224 \pm 0,064$ & $0,0338 \pm 0,0052$ & $2,858 \pm 0,839 *$ \\
\hline
\end{tabular}



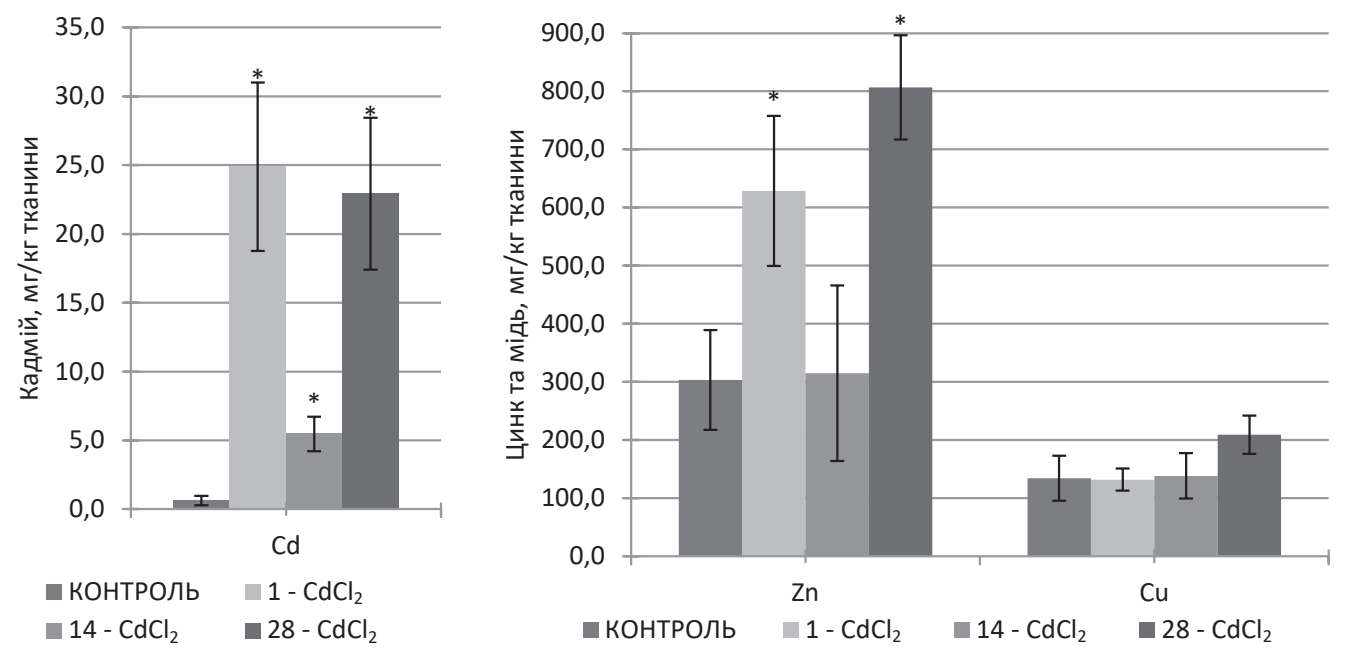

Рис. 3. Вміст кадмію, цинку та міді в крові експериментальних тварин за умов впливу кадмій хлориду.
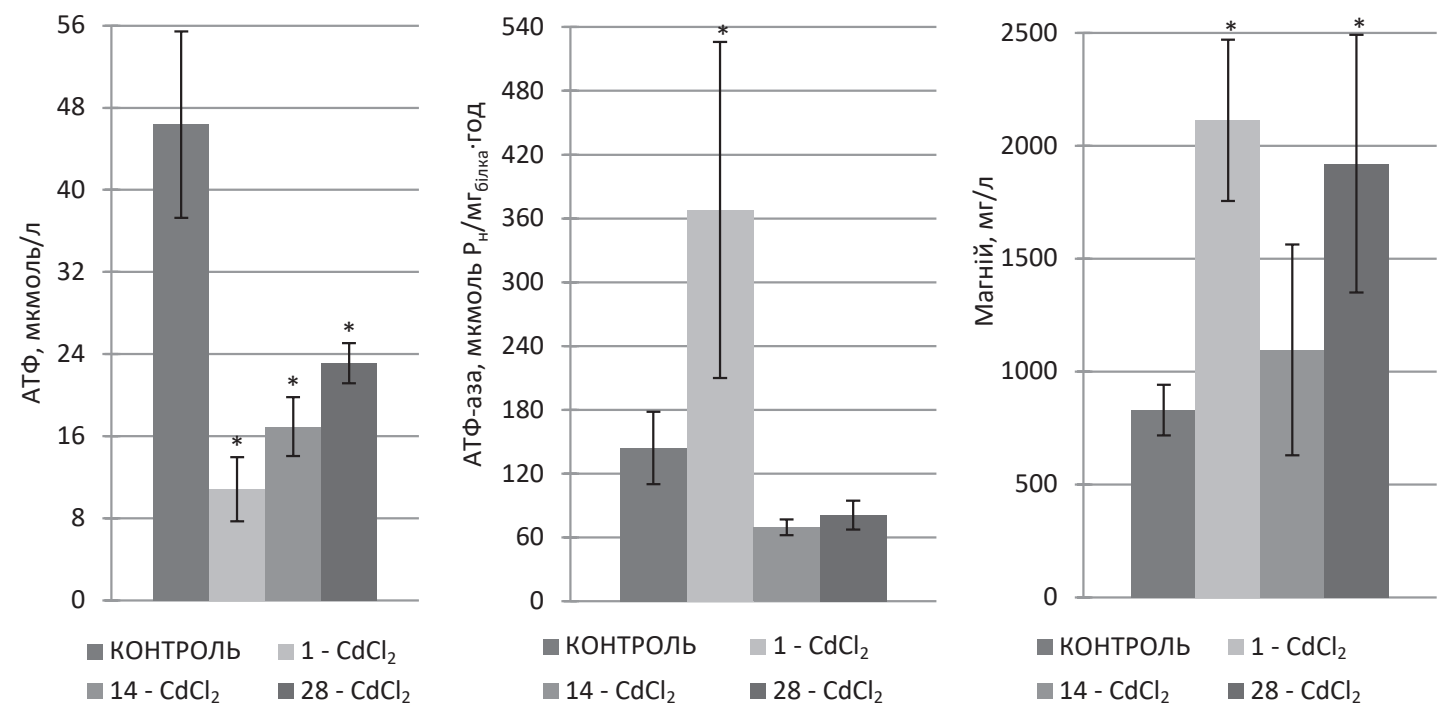

Рис. 4. Вплив кадмій хлориду на концентрацію аденозинтрифосорорної кислоти і магнію та активність АТФ-ази в сироватці крові експериментальних тварин.

Проведений кореляційний аналіз залежності між показниками енергетичного обміну в серцевій тканині на 14-ту добу показав, що між концентрацією молочної кислоти та вмістом піровиноградної кислоти коефріцієнт кореляції становив $r=0,852728$, а між рівнем пірувату та активністю лактатдегідрогенази - r=0,841508, що вказувало на сильний зв'язок між досліджуваними показниками. На 28-му добу дослідження в сироватці крові спостерігали негативний кореляційний зв'язок між концентраціями лактату та пірувату, який становив $\mathrm{r}=-0,791166$.

Наші результати підтвердилися кореляційним зв'язком між показниками сироватки крові та серцевого м'яза. На 28-му добу дослідження встановлено зростання рівня глюкози та активності лактатдегідрогенази в сироватці крові, а в серці - зниження, і коефріцієнти кореляції стано- вили, відповідно, r=-0,780261 (для глюкози) та $r=-0,820984$ (для лактатдегідрогенази).

ВИСНОВКИ. 1. Отримані експериментальні дані вказують на посилене використання глюкози серцевим м'язом (ії рівень достовірно зменшується), при цьому достовірно підвищується концентрація молочної кислоти і знижується рівень піровиноградної кислоти. Це свідчить про те, що окиснення глюкози відбувається за анаеробних умов, тобто клітини серця перебувають у стані гіпоксії, яку викликає дія іонів кадмію. Також достовірно знижується активність лактатдегідрогенази в серці, однак у сироватці крові вона достовірно зростає.

2. Енергетичні запаси серцевої тканини також вичерпуються, що підтверджується достовірним зниженням концентрації аденозинтрисроссрорної кислоти та активності АТФ-ази. 


\section{СПИСОК ЛІТЕРАТУРИ}

1. Трахтенберг И. М. Проблемы нормы в токсикологии: современные представления и методические подходы, основные параметры и константы / И. М. Трахтенберг. - М. : Медицина, 1991. - 206 с.

2. Скальный А. В. Биоэлементы в медицине / А. В. Скальный, И. А. Рудаков. - М. : ОНИКС 21 век, Мир, 2004. - 272 с.

3. Sethi P. K. Cadmium exoponsure: health hazards of silver cottage industry in developing countries / P. K. Sethi, D. J. Khandelwal // Med. Toxicol. - 2006. 2. - P. 14-15.

4. Дереча Л. М. Макро- і мікроелементи: сучасні уявлення про їх фрункціональне значення в теплокровному організмі / Л. М. Дереча, В. В. Мясоєдов // Експерим. і клініч. медицина. - 2007. - № 4. - С. 21-27.

5. Макро- та мікроелементи (обмін, патологія та методи визначення) : монографрія / [М.В.Погорєлов, В. І. Бумейстер, Г. Ф. Ткач та ін.]. - Суми : Вид-во СумДУ, 2010. - 147 с.

6. Чмиленко Ф. О. Методи атомної спектроскопії: атомно-абсорбційний спектральний аналіз : навч. посіб. / Ф. О. Чмиленко, Т. М. Деркач. - Дніпро : РВВ ДНУ, 2002. -120 c.

7. Identification and catalytic properties of $\mathrm{Mg}^{2+}$-dependent ATP-hydrolase of plasmic membrane of Bacillus sp. B4253 capable to gold accumulation / G. V. Danilovich, T. G. Gruzina, Z. R. Ulberg, S. O. Kosterin // Укр. біохім. журн. - 2004. - 76 (5). - С. 45-51.

8. Біологічна хімія з біохімічними методами дослідження : підручник / О. Я. Скляров, Н.В.Фартушок, Л. Д. Сойка, І. С. Смачило. - К. : Медицина, 2009. $352 \mathrm{c}$.

9. Методи лабораторної клінічної діагностики хвороб тварин / [В. І. Левченко, В. І. Головаха, І. П. Кондрахін та ін.] ; за ред. В. І. Левченка. - К. : Аграрна освіта, 2010. - 437 c.

10. Біохімія : практикум / [Д. О. Мельничук, С. Д. Мельничук, Л. Г. Калачнюк та ін.] ; за ред. Д. О. Мельничука. - К. : НУБіп України, 2012. -528 с.

11. Майборода Р. Комп'ютерна статистика - професійний старт / Р. Майборода. - К. : ВПЦ “Київський університет", 2018. - 482 с.

\section{REFERENCES}

1. Trakhtenberg, I.M. (1991). Problemy normy $v$ toksikologii: sovremennye predstavleniya i metodicheskie podkhody, osnovnye parametry i konstanty [Problems of norm in toxicology: modern concepts and methodical approaches, basic parameters and constants]. Moscow: Meditsina [in Russian].

2. Skalnyy, A.V., \& Rudakov, I.A. (2004). Bioelementy $v$ meditsine [Bioelements in medicine]. Moscow: Izdatelskii dom ONIKS 21vek [in Russian].

3. Sethi, P.K., \& Khandelwal, D.J. (2006). Cadmium exoponsure: health hazards of silver cottage industry in developing countries. Med. Toxicol., 2, 14-15.

4. Derecha, L.M., \& Miasoiedov, V.V. (2007). Makroi mikroelementy: suchasni uiavlennia pro yikh funktsionalne znachennia v teplokrovnomu orhanizmi [Macro- and trace elements: modern ideas about their functional significance in the warm-blooded organism]. Eksperymentalna $i$ klinichna medytsyna - Experimental and Clinical Medicine, 4, 21-27 [in Ukrainian].

5. Pohorielov, M.V., Bumeister, V.I., Tkach, H.F., Bonchev, S.D., Sikora, V.Z., Sukhodub, L.F., \& Danylchenko, S.M. (2010). Makro- ta mikroelementy (obmin, patolohiia ta metody vyznachennia): monohrafiia [Macro and microelements (metabolism, pathology and methods of determination): monograph]. Sumy: Vyd-vo SumDU [in Ukrainian].
6. Chmylenko, F.O., \& Derkach, T.M. (2002). Metody atomnoi spektroskopii: atomno-absorbtsiinyi spektralnyi analiz: Navch. posib. [Methods of atomic spectroscopy: Atomic-absorption spectral analysis: Teaching manual]. Dnipro: RVV DNU [in Ukrainian].

7. Danilovich, G.V., Gruzina, T.G., Ulberg, Z.R., \& Kosterin, S.O. (2004). Identification and catalytic properties of $\mathrm{Mg}^{2+}$-dependent ATP-hydrolase of plasmic membrane of Bacillus sp. B4253 capable to gold accumulation. Ukr. biokhim. zhurn. - Ukrainian Biochemical Journal, 76 (5), 45-51.

8. Skliarov, O.Ya., Fartushok, N.V., Soika, L.D., \& Smachylo, I.S. (2009). Biolohichna khimiia z biokhimichnymy metodamy doslidzhennia: pidruchnyk [Biological chemistry with biochemical methods of research: textbook]. Kyiv: Medytsyna [in Ukrainian].

9. Levchenko, V.I., Holovakha, V.I., \& Kondrakhin, I.P. (2010). Metody laboratornoi klinichnoi diahnostyky khvorob tvaryn [Methods of laboratory clinical diagnostics of animal diseases]. Kyiv: Ahrarna osvita [in Ukrainian].

10. Melnychuk, D.O., Melnychuk, S.D., Kalachniuk, L.H., Shevriakov, M.V., \& Kalachniuk, H.I. (2012). Biokhimiia: praktykum [Biochemistry: a workshop]. Kyiv: NUBiP Ukrainy [in Ukrainian].

11. Maiboroda, R. (2018). Kompiuterna statystyka profesiinyi start [Computer statistics - professional start]. Kyiv: VPTs Kyivskyi universytet [in Ukrainian]. 


\section{ПОКАЗАТЕЛИ ЭНЕРГЕТИЧЕСКОГО ОБМЕНА В СЕРДЕЧНОЙ ТКАНИ ЭКСПЕРИМЕНТАЛЬНЫХ ЖИВОТНЫХ В УСЛОВИЯХ ВЛИЯНИЯ КАДМИЙ ХЛОРИДА}

\section{Резюме}

Вступление. Катионы кадмия могут поступать в организм человека и животных с пищей, питьевой водой и атмосфрерным воздухом. Их действие заключается в угнетении фуункционального состояния митохондрий, что приводит к истощению энергетических ресурсов и нарущению ряда жизненно важных процессов. Кадмий, проникая в клетки, взаимодействует с меркаптогруппами, подавляет энзимные системы энергообеспечения путем замещения двухвалентных металлов, входящих в состав энзимов.

Цель исследования - выяснить состояние энергетического обмена в сердечной мышце экспериментальных животных (крыс) в условиях влияния кадмий хлорида.

Методы исследования. Интоксикацию осуществляли путем внутримышечного введения кадмий хлорида в дозе 1/10 LD 2-я - экспериментальные, которым вводили кадмий хлорид. Забор материала проводили после декапитации под тиопенталовым наркозом на 1-е, 14-е, 28-е сутки после завершения ввода токсиканта. Показатели энергетического обмена определяли следующим образом: активность АТФ-азы, лактатдегидрогеназы - энзиматическим методом; концентрацию глюкозы - глюкооксидазным методом; уровень пировиноградной, молочной, аденозинтрифосфорной (АТФ) кислот - спектрофотометрически; содержание макро- и микроэлементов ( $\mathrm{Cd}, \mathrm{Zn}, \mathrm{Cu}, \mathrm{Mg})$ - с помощью атомно-абсорбционного спектрофоотометра.

Результаты и обсуждение. Полученные результаты свидетельствуют об усиленном использовании глюкозы сердечной мышцей анаэробным путем, так как наблюдали повышение концентрации молочной кислоты. Это подтвердило литературные данные о развитии гипоксии в условиях действия ионов кадмия. В то же время отмечено снижение уровня аденозинтрифоосфорной кислоты, а также активности АТФ-азы в ткани сердца. Установлено увеличение содержания магния (активатора АТФ-азы) и цинка (активатора лактатдегидрогеназы) в сердие экспериментальных животных.

Вывод. Результаты проведенных исследований указывают на нарушение энергетического обеспечения тканей сердечной мышцы в условиях кадмиевой интоксикации, что подтверждается активацией анаэробного окисления глюкозы, снижением ее уровня и содержания аденозинтрифросфорной кислоты в миокарде.

КЛЮЧЕВЫЕ СЛОВА: энергетический обмен; кадмий хлорид; $\mathrm{Na}^{+}, \mathrm{K}^{+}$-активирующая, $\mathrm{Mg}^{2+}$-зависимая АТФ-аза; аденозинтрифоссорная кислота; глюкоза; лактатдегидрогеназа.

\section{INDEXES OF ENERGY METABOLISM IN HEART TISSUE OF EXPERIMENTAL ANIMALS UNDER CONDITIONS OF THE INFLUENCE OF CADMIUM CHLORIDE}

\section{Summary}

Introduction. Cadmium chloride can enter the body of humans and animals with food, drinking water and atmospheric air. Their effect is to suppress the functional state of mitochondria, which leads to the depletion of energy resources and the violation of a number of vital processes. Cadmium, penetrating into cells, interacts with mercaptogroups, suppresses enzyme systems of energy supply, by replacing bivalent metals that are part of enzymes.

The aim of the study - to determine the state of energy metabolism in the cardiac muscle of experimental animals (rats) under conditions of cadmium chloride.

Research Methods. Intoxication was carried out by intravenous administration of cadmium chloride at a dose of 1/10 LD 50 for 10 days. Animals were divided into two groups: intact and experimental, which were injected with cadmium chloride. The material was collected after decapitation under tiopental anesthesia at $1^{\text {st }}, 14^{\text {th }}, 28^{\text {th }}$ day after the completion of the administration of the toxicant. Indicators of energy metabolism were determined as follows: 
the activity of ATPase, lactate dehydrogenase was determined by the enzymatic method; concentration of glucose glucoxidase method, the level of pyruvate, lactate and adenosine triphosphate (ATP) was determined spectrophotometrically. The content of macro- and micronutrients $(\mathrm{Cd}, \mathrm{Zn}, \mathrm{Cu}, \mathrm{Mg})$ was determined using an atomic absorption spectrophotometer.

Results and Discussion. The obtained results testify to the increased use of glucose by the cardiac muscle in anaerobic way, as there is an increase in the concentration of lactic acid. This is confirmed by the literature sources on the development of hypoxia under the conditions of cadmium ions. At that time, the level of adenosine triphosphoric acid decreases as well as the activity of ATPase in the heart tissue. We also observed the increase in the content of magnesium (the activator of ATPase) and zinc (the activator of lactate dehydrogenase) in the heart of experimental animals.

Conclusion. The conducted studies indicate a violation of the energy supply of tissue of the heart muscle for cadmium intoxication, which is confirmed by the activation of glucose anaerobic oxidation, a decrease in its level and the content of ATP in the myocardium.

KEY WORDS: energy metabolism; cadmium chloride; $\mathrm{Na}^{+}, \mathrm{K}^{+}, \mathrm{Mg}^{2+}$-ATPase; adenosine triphosphoric acid; glucose; lactate dehydrogenase.

Отримано 15.01.19

Адреса для листування: Л. Д. Курас, Івано-Франківський національний медичний університет, вул. Галицька, 2, Івано-Франківськ, 76018, Україна, e-mail: kuras1205@ukr.net. 